\title{
Regio- and stereoselective reactions of a rhodanine derivative with optically active 2-methyl- and 2-phenyloxirane
}

Fu, Changchun ; Thrane, Marie V ; Linden, Anthony ; Heimgartner, Heinz

\begin{abstract}
The reaction of a rhodanine derivative (= (Z)-5-benzylidene-3-phenyl-2-thioxo-1,3-thiazolidin4-one; 1) with (S)-2-methyl-oxirane (2) in the presence of $\mathrm{SiO} 2$ in dry $\mathrm{CH} 2 \mathrm{Cl} 2$ for 10 days led to two diastereoisomeric spirocyclic 1,3-oxathiolanes 3 and 4 with the Me group at $\mathrm{C}(2)$ (Scheme 2). The analogous reaction of 1 with (R)-2-phenyloxirane (5) afforded also two diastereoisomeric spirocyclic 1,3oxathiolanes 6 and 7 bearing the $\mathrm{Ph}$ group at $\mathrm{C}(3)$ (Scheme 3). The structures of 3, 4, 6, and 7 were confirmed by X-ray crystallography (Figs. 1 and 2). These results show that oxiranes react selectively with the thiocarbonyl group $(\mathrm{C}=\mathrm{S})$ in 1 . Furthermore, the nucleophilic attack of the thiocarbonyl Satom at the $\mathrm{SiO} 2$-activated oxirane ring proceeds with high regio- and stereoselectivity via an SN2-type mechanism.
\end{abstract}

DOI: https://doi.org/10.1016/j.tet.2004.04.066

Posted at the Zurich Open Repository and Archive, University of Zurich

ZORA URL: https://doi.org/10.5167/uzh-79824

Journal Article

Originally published at:

Fu, Changchun; Thrane, Marie V; Linden, Anthony; Heimgartner, Heinz (2004). Regio- and stereoselective reactions of a rhodanine derivative with optically active 2-methyl- and 2-phenyloxirane. Tetrahedron, 60:5407-5412.

DOI: https://doi.org/10.1016/j.tet.2004.04.066 


\title{
Regio- and Stereoselective Reactions of a Rhodanine Derivative with Optically Active 2-Methyl- and 2-Phenyloxirane
}

\author{
Changchun Fu, Marie V. Thrane, ${ }^{\dagger}$ Anthony Linden, and Heinz Heimgartner \\ Institute of Organic Chemistry, University of Zürich, Winterthurerstrasse 190, \\ CH-8057 Zürich, Switzerland
}

\begin{abstract}
The reaction of a rhodanine derivative (= 5-benzylidene-3-phenyl-2thioxo-1,3-thiazolidin-4-one; 1) with $(S)$-2-methyloxirane (2) in the presence of $\mathrm{SiO}_{2}$ in dry $\mathrm{CH}_{2} \mathrm{Cl}_{2}$ for $10 \mathrm{~d}$ led to two diastereoisomeric spirocyclic 1,3oxathiolanes 3 and 4 with the Me group at C(2) (Scheme 2). The analogous reaction of 1 with $(R)$-2-phenyloxirane (5) afforded also two diastereoisomeric spirocyclic 1,3-oxathiolanes 6 and 7 bearing the $\mathrm{Ph}$ group at $\mathrm{C}(3)$ (Scheme 3). The structures of 3, 4, 6, and 7 were confirmed by X-ray crystallography (Figs. 1 and 2). These results show that oxiranes react selectively with the thiocarbonyl group $(\mathrm{C}=\mathrm{S})$ in 1. Furthermore, the nucleophilic attack of the thiocarbonyl S-atom at the $\mathrm{SiO}_{2}$-activated oxirane ring proceeds with high regio- and stereoselectivity via an $\mathrm{S}_{\mathrm{N}}$ 2-type mechanism.
\end{abstract}

\section{Introduction}

The reaction of thiocarbonyl compounds with oxiranes in the presence of a Lewis acid to give 1,3-oxathiolanes has been investigated thoroughly in recent years. ${ }^{1-7}$ All results reported indicate that the reactions proceed with high regio- and

Keywords: rhodanine; oxiranes; 1,3-oxathiolanes; thiocarbonyl group; $\mathrm{SiO}_{2} ; \mathrm{S}_{\mathrm{N}} 2$-type reaction. Corresponding author. Tel.: +41-1-6354282; fax: +41-1-6356812; e-mail:heimgart@oci.unizh.ch ${ }^{\dagger}$ Department of Chemistry, Technical University of Denmark, DK-2800 Kgs. Lyngby, Denmark; stay at the University of Zurich, 10. 2002-01. 2003. 
stereoselectivity via an $\mathrm{S}_{\mathrm{N}}$ 2-type mechanism. In the case of alkyl-substituted oxiranes, the thiocarbonyl S-atom attacks preferably at $\mathrm{C}(3)$ leading to the 5substituted 1,3-oxathiolanes with retention of the configuration. On the other hand, the nucleophilic attack occurs mainly at $\mathrm{C}(2)$ of phenyloxirane to yield the 4-phenyl-substituted products via inversion of the configuration (Scheme 1).

\section{Scheme 1}

With the aim of establishing the scope and limitation of the formation of 1,3oxathiolanes, the reactions of a rhodanine derivative, i.e. 5-benzylidene-3-phenyl2-thioxo-1,3-thiazolidin-4-one (1) with optically active oxiranes were carried out. In the present paper, the results with $(S)$-2-methyloxirane (2) and (R)-2phenyloxirane (5) are described.

\section{Results}

\subsection{Reaction of the rhodanine derivative 1 with $(S)$-2-methyloxirane (2).}

The reaction of $\mathbf{1}$ with $\mathbf{2}$ in a molar ratio of 1:4 was carried out in dry $\mathrm{CH}_{2} \mathrm{Cl}_{2}$ at room temperature under an $\mathrm{N}_{2}$ atmosphere in the presence of $\mathrm{SiO}_{2}{ }^{*}$ After stirring for $10 \mathrm{~d}$, filtration and the usual workup by means of column chromatography (CC) and preparative TLC (PLC) gave two diastereoisomeric spirocyclic 1,3oxathiolanes $\mathbf{3}$ and $\mathbf{4}$ in 23 and 19\% yield, respectively. The starting material $\mathbf{1}$ was recovered in $52 \%$ yield (Scheme 2). The enantiomeric excess (ee) of the products was determined by analytical HPLC ((S,S)-Whelk-O 1, hexane/AcOEt $3: 1)$.

\footnotetext{
\# The analogous reaction with racemic 2-methyloxirane leading to racemic products of type $\mathbf{3}$ and 4 was also carried out.
} 


\section{Scheme 2}

The structures of $\mathbf{3}$ and $\mathbf{4}$ were assigned on the basis of the elemental analyses, MS, IR, ${ }^{1} \mathrm{H}-$ and ${ }^{13} \mathrm{C}-\mathrm{NMR}, 1 \mathrm{D}-\mathrm{NOESY}$, HSQC, HSQC-TOCSY, and HMBC spectra, which clearly indicated the relative configurations of the products. For example, on irradiation of $\mathrm{H}-\mathrm{C}(2)$ at $4.50 \mathrm{ppm}$, the 1D-NOESY spectrum of 4 showed one NOE-signal for two ortho $\mathrm{H}$-atoms of the $\mathrm{PhN}$ residue at 7.40-7.38 ppm, whereas this signal was missing in the analogous experiment with $\mathbf{3}$. Finally, the structures were established by X-ray crystallography (Fig. 1).

Fig. 1

The crystals of $\mathbf{3}$ and $\mathbf{4}$ were enantiomerically pure and the absolute configurations of the molecules were determined independently by the diffraction experiments. Therefore, 3 has the $(2 S, 5 R)$-configuration, whereas 4 is the $(2 S, 5 S)$ diastereoisomer. In the case of $\mathbf{3}$, the oxathiolane ring has an envelope conformation with $\mathrm{C}(3)$ as the envelope flap. The other five-membered ring shows a half-chair conformation twisted on $\mathrm{S}(6)-\mathrm{C}(5)$, although the puckering is quite shallow and distorted towards an envelope. Both five-membered rings of $\mathbf{4}$ have a half-chair conformation twisted on $\mathrm{C}(2)-\mathrm{C}(3)$ and $\mathrm{S}(6)-\mathrm{C}(5)$, respectively.

The formation of $\mathbf{3}$ and $\mathbf{4}$ proceeded with retention of the configuration at $\mathrm{C}(2)$ of the oxirane 2 because the nucleophilic attack of the thiocarbonyl S-atom took place at $\mathrm{C}(3)$, leading to the intermediate A. Ring closure via nucleophilic addition of the $\mathrm{O}$-atom at the thiocarbonylium group from the si- or $r e$-side leads to 3 and $\mathbf{4}$, respectively. 


\subsection{Reaction of the rhodanine derivative 1 with $(R)-2$-phenyloxirane (5).}

The analogous reaction of $\mathbf{1}$ with $\mathbf{5}$ (molar ratio $1: 2$, dry $\mathrm{CH}_{2} \mathrm{Cl}_{2}$, room temperature, $10 \mathrm{~d}, \mathrm{~N}_{2}$ atmosphere) in the presence of $\mathrm{SiO}_{2}$ gave two diastereoisomeric spiroheterocycles 6 and 7 in 37 and $8 \%$ yield, respectively. In addition, $\mathbf{1}$ was recovered in $51 \%$ yield (Scheme 3). A likely intermediate is $\mathbf{B}$. The determination of the ee-values by means of HPLC showed that $\mathbf{6}$ was formed via inversion of the configuration at $\mathrm{C}(2)$ of $\mathbf{5}$. The formation of $\mathbf{7}$ proceeded with lower stereoselectivity and partial racemization (9\%) was observed. ${ }^{\S}$ The structures of 6 and 7 were assigned on the basis of their elemental analyses and spectroscopic data, particularly 2D-NOESY, HSQC, HSQC-TOCSY, and HMBC spectra, and they were confirmed by X-ray crystallography (Fig. 2).

\section{Scheme 3}

The examination of a Dreiding-model of $\mathbf{6}$ shows that the distances between the ortho- $\mathrm{H}$ atoms of $\mathrm{Ph}-\mathrm{C}(3)$ and those of $\mathrm{Ph}-\mathrm{N}$ are small, in agreement with the 2D-NOESY spectrum of $\mathbf{6}$, which shows one cross-signal between the ortho-H atoms of $\mathrm{Ph}-\mathrm{N}$ at $7.33-7.30 \mathrm{ppm}$ and those of $\mathrm{Ph}-\mathrm{C}(3)$ at $6.55 \mathrm{ppm}$. Therefore, the configuration of $\mathbf{6}$ should be $3 S, 5 S$. Similarly, the 2D-NOESY spectrum of 7 shows one relevant cross-signal between the ortho- $\mathrm{H}$ atoms of $\mathrm{Ph}-\mathrm{N}$ at $7.49-7.45$ ppm and $\mathrm{H}-\mathrm{C}(3)$ at $4.20 \mathrm{ppm}$, which, on the assumption that the reaction proceeded again with inversion of the configuration of $\mathbf{5}$, indicates the $(3 S, 5 R)$ configuration of 7 .

Fig. 2

\footnotetext{
$\S$ The analogous reaction with racemic 2-phenyloxirane gave the corresponding racemic products.
} 
The crystals of $\mathbf{6}$ are enantiomerically pure and the absolute configuration of the molecule has been determined independently by the diffraction experiment and found to have the $(3 S, 5 S)$-configuration. There are two symmetry-independent molecules in the asymmetric unit. Both are of the same enantiomer and differ primarily in the orientations of the phenyl rings, particularly the $\mathrm{Ph}-\mathrm{C}(3)$, which in molecule $\mathrm{A}$ is rotated by $70^{\circ}$ with respect to its orientation in molecule $\mathrm{B}$. The 1,3-thiazolidine ring in molecule $\mathrm{A}$ has a flattened envelope conformation with the spiro $\mathrm{C}(5)$-atom, as the envelope flap, while in molecule $\mathrm{B}$, this ring is planar. The other five-membered ring in each molecule has the envelope conformation with $\mathrm{C}(2)$ acting as the envelope flap.

Although the enantiomeric excess of 7 amounted to $91 \%$ according to the analytical HPLC and the isolated product was optically active, the crystal used for the crystal-structure determination was racemic since the space group is centrosymmetric. The oxathiolane ring has a half-chair conformation twisted on $\mathrm{C}(2)-\mathrm{C}(3)$. The other five-membered ring has a distorted shallow envelope conformation with $\mathrm{S}(6)$ as the envelope flap. The distortion is towards a half-chair twisted on $\mathrm{S}(6)-\mathrm{C}(5)$.

\section{Discussion and Conclusion}

The five-membered ring of the rhodanine derivative $\mathbf{1}$ has been shown to be planar and the bond lengths involving $\mathrm{S}(1)$ indicate significant delocalization of the lone-pair electrons of $S(1)$ with the adjacent $C(2)=S$ and $C(5)=C\left(1^{\prime}\right)$ systems. ${ }^{9}$ Therefore, the nucleophilic attack of $\mathbf{1}$ at the Lewis acid-complexed oxiranes could occur, in principle, either at the thiocarbonyl group $(\mathrm{C}(2)=\mathrm{S})$ or at the $\mathrm{C}(5)=\mathrm{C}\left(1^{\prime}\right)$ double bond. A third possibility is the reaction with the carbonyl 
group $(\mathrm{C}(4)=\mathrm{O})$. However, the results presented show that the reactions of $\mathbf{1}$ with 2 and 5 take place chemoselectively at the thiocarbonyl group $(\mathrm{C}(2)=\mathrm{S})$ to yield the spirocyclic 1,3-oxathiolanes with high regio- and stereoselectivity. The results show that the $\mathrm{C}=\mathrm{S}$ group is the most reactive nucleophile in $\mathbf{1}$. We assume that the reactions proceed via an $\mathrm{S}_{\mathrm{N}} 2$-type mechanism, whereby the nucleophilic thiocarbonyl S-atom favorably attacks the $\mathrm{C}(3)$-atom $(\mathrm{O}-\mathrm{C}(3)$ cleavage) of the activated (S)-2-methyloxirane (2) leading to intermediate A with retention of the configuration (Scheme 2). On the other hand, the addition to $(R)$-2-phenyloxirane (5) occurs selectively at the $\mathrm{C}(2)$-atom $(\mathrm{O}-\mathrm{C}(2)$ cleavage) with inversion of the configuration leading to intermediate B (Scheme 3). The partial loss of the stereochemical integrity of the phenyloxirane moiety in the formation of $\mathbf{7}$ may be interpreted by a competing reaction in which the oxirane ring-opening occurs prior to the nucleophilic attack $\left(\mathrm{S}_{\mathrm{N}} 1\right.$-type).

\section{Experimental}

\subsection{General}

See ref. ${ }^{10}$ Optical rotations: Perkin-Elmer 241 polarimeter $(c=1$ in THF). IR Spectra: $\mathrm{KBr}, \mathrm{cm}^{-1}$. ${ }^{1} \mathrm{H}$ - and ${ }^{13} \mathrm{C}-\mathrm{NMR}$ Spectra: in $\mathrm{CDCl}_{3}$. Enantiomeric excesses (ee) were determined by anal. HPLC on a (S,S)-Whelk-O 1 column (hexane/AcOEt 3:1).

\subsection{Reactions of 5-benzylidene-3-phenyl-2-thioxo-1,3-thiazolidin-4-one (1) with (S)-2-methyloxirane (2) and (R)-2-phenyloxirane (5).}

General procedure. To a solution of $\mathbf{1}(\mathrm{ca} .1 \mathrm{mmol})$ and oxirane $\mathbf{2}$ or $\mathbf{5}(2-4 \mathrm{mmol})$ in dry $\mathrm{CH}_{2} \mathrm{Cl}_{2}(10-15 \mathrm{~mL})$ under an $\mathrm{N}_{2}$ atmosphere, $4.5 \mathrm{~g}$ of silica gel $\left(\mathrm{SiO}_{2}\right)$ were added at rt. After stirring the suspension for $10 \mathrm{~d}$ at $\mathrm{rt}$, the mixture was filtered and 
the residue was washed with ethyl acetate (AcOEt, 4×). Then, the combined filtrate was evaporated i.v. The products were separated by chromatography $\left(\mathrm{SiO}_{2}\right.$, hexane/AcOEt; CC, MPLC, or prep. TLC (PLC)).

\subsubsection{Reaction of 1 with (S)-2-methyloxirane (2).}

Reaction of 1 (446 mg, $1.5 \mathrm{mmol})$ with $2(348 \mathrm{mg}, 6 \mathrm{mmol})$ and $4.5 \mathrm{~g}$ of $\mathrm{SiO}_{2}$ at rt, $10 \mathrm{~d}$; CC and prep. TLC (hexane/AcOEt 20:1) yielded $120 \mathrm{mg}$ (23\%) of 3 and $103 \mathrm{mg}(19 \%)$ of $\mathbf{4}$, and $230 \mathrm{mg}(52 \%)$ of the starting material (1) was recovered .

(2S,5R)-7-Benzylidene-2-methyl-9-phenyl-1-oxa-4,6-dithia-9-azaspiro[4.4]nonan-8-one (3). Colorless crystals. M.p. $161.4-162.5^{\circ} .[\alpha]_{D}^{24}=-9.3$ (>98\% ee). IR: $3061 w, 3043 w, 3026 w, 3012 w, 2979 w, 2925 w, 2815 w, 1703 s, 1611 m, 1594 w$, $1493 m, 1447 w, 1377 w, 1356 s, 1337 m, 1222 m, 1194 m, 1171 w, 1143 m, 1131 m$, $1081 m, 1020 s, 986 s, 926 m, 897 w, 870 w, 806 w, 758 m, 733 m, 697 m, 687 m .{ }^{1} \mathrm{H}-$ NMR (300 MHz): 7.66 ( $s, \mathrm{PhCH}) ; 7.52-7.30$ ( $m, 10$ arom. H); 4.41-4.30 (m, H$\mathrm{C}(2)) ; 2.89(d d, J=10.4,3.9,1 \mathrm{H}-\mathrm{C}(3)) ; 2.15$ (t-like, $J \approx 10.5,1 \mathrm{H}-\mathrm{C}(3)) ; 1.34$ $(d, J=6.0, \mathrm{Me}) .{ }^{13} \mathrm{C}-\mathrm{NMR}(75.5 \mathrm{MHz}): 164.9(s, \mathrm{C}=\mathrm{O}) ; 135.4,134.7$ (2s, 2 arom. C); $130.5,129.8,128.84,128.77,128.73(5 d, 10$ arom. $\mathrm{CH}) ; 127.8(d, \mathrm{PhCH})$; $124.7(s, \mathrm{C}(7))$; $109.9(s, \mathrm{C}(5)) ; 80.1(d, \mathrm{C}(2)) ; 40.8(t, \mathrm{C}(3)), 18.2$ ( $q$, Me). ESIMS $(\mathrm{MeOH}+\mathrm{NaI}): 733\left(15,[2 M+\mathrm{Na}]^{+}\right), 378\left(100,[M+\mathrm{Na}]^{+}\right)$. Anal. calc. for $\mathrm{C}_{19} \mathrm{H}_{17} \mathrm{NO}_{2} \mathrm{~S}_{2}$ (355.48): C 64.20, H 4.82, N 3.94, S 18.04; found: C 64.27, H 4.90, N 3.93, S 17.97. Crystals of $\mathbf{3}$ suitable for an X-ray crystal-structure analysis were grown from $\mathrm{Et}_{2} \mathrm{O} /$ hexane.

(2S,5S)-7-Benzylidene-2-methyl-9-phenyl-1-oxa-4,6-dithia-9-azaspiro[4.4]nonan-8-one (4). Colorless crystals. M.p. $155.0-156.6^{\circ} \cdot[\alpha]_{D}^{24}=+114.6(>98 \%$ ee). IR: $3076 w, 3055 w, 3039 w, 3023 w, 2989 w, 2970 w, 2943 w, 2928 w, 2862 w$, 
$2853 w, 1679 s, 1609 m, 1594 w, 1493 m, 1447 w, 1436 w, 1373 m, 1360 s, 1312 w$, $1289 w, 1238 w, 1219 w, 1191 m, 1178 w, 1170 w, 1135 m, 1104 m, 1074 w, 1058 w$, 1014s, 982s, 931s, 806w, 761s, 732s, 694s. ${ }^{1} \mathrm{H}-\mathrm{NMR}$ (500 MHz): 7.65 (s, PhCH); 7.50-7.41 ( $m, 7$ arom. H); 7.40-7.38 (m, 2 arom. H); 7.35-7.32 (m, 1 arom. H); 4.51-4.47 (m, H-C(2)); $2.77(d d, J=10.6,3.6,1 \mathrm{H}-\mathrm{C}(3)) ; 2.65(d d, J=10.7,5.7$,

$1 \mathrm{H}-\mathrm{C}(3)) ; 1.41(d, J=6.3, \mathrm{Me}) .{ }^{13} \mathrm{C}-\mathrm{NMR}(125.8 \mathrm{MHz}): 164.4(s, \mathrm{C}=\mathrm{O}) ; 135.3$, 134.7 (2s, 2 arom. C); 130.7, 129.7, 129.1, 129.0, 128.73, 128.70 (6d, 10 arom. $\mathrm{CH}) ; 127.3(d, \mathrm{PhCH}) ; 124.5(s, \mathrm{C}(7)) ; 110.6(s, \mathrm{C}(5)) ; 81.8(d, \mathrm{C}(2)) ; 41.0(t$, $\mathrm{C}(3)), 19.5(q, \mathrm{Me})$. ESI-MS (MeOH+NaI): $733\left(25,[2 M+\mathrm{Na}]^{+}\right), 378(100$, $\left.[M+\mathrm{Na}]^{+}\right)$. Anal. calc. for $\mathrm{C}_{19} \mathrm{H}_{17} \mathrm{NO}_{2} \mathrm{~S}_{2}$ (355.48): $\mathrm{C}$ 64.20, H 4.82, N 3.94, S 18.04; found: C 64.18, H 4.94, N 3.91, S 18.02. Crystals of 4 suitable for an X-ray crystal-structure analysis were grown from $\mathrm{Et}_{2} \mathrm{O} / \mathrm{hexane}$.

\subsubsection{Reaction of 1 with (R)-2-phenyloxirane (5).}

Reaction of 1 (297 mg, $1 \mathrm{mmol})$ with $5(240 \mathrm{mg}, 2 \mathrm{mmol})$ and $4.5 \mathrm{~g}$ of $\mathrm{SiO}_{2}$ at rt, $10 \mathrm{~d}$; CC and MPLC (hexane/AcOEt 15:1) yielded $153 \mathrm{mg}(37 \%)$ of 6 and $32 \mathrm{mg}$ (8\%) of 7, and $151 \mathrm{mg}(51 \%)$ of the starting material (1) was recovered (Scheme $3)$.

\section{(3S,5S)-7-Benzylidene-3,9-diphenyl-1-oxa-4,6-dithia-9-azaspiro[4.4]nonan-8-} one (6). Colorless crystals. M.p. $218.6-222.9^{\circ}$ (partially decomposed). $[\alpha]_{D}^{24}=$ - 12.3 (98\% ee). IR: 3058w, 3032w, 2970w, 2926w, 2871w, 1690vs, 1608m, $1594 w, 1493 s, 1453 w, 1446 m, 1358 v s, 1347 v s, 1291 w, 1280 w, 1243 m, 1234 s$, $1201 s, 1185 w, 1171 m, 1155 m, 1080 w, 1072 w, 1053 v s, 1041 v s, 1002 w, 967 m$, $940 w, 914 w, 898 m, 864 w, 797 m, 774 w, 762 m, 754 m, 735 m, 728 m, 702 s, 693 s$, 687s. ${ }^{1} \mathrm{H}-\mathrm{NMR}(600 \mathrm{MHz}): 7.62(s, \mathrm{PhCH}) ; 7.45$ (d, $J=7.5,2$ arom. H); 7.427.27 ( $m, 8$ arom. H); 7.02 ( $t, J=7.4,1$ arom. H); 6.92 (t-like, $J \approx 7.7,2$ arom. H); 
$6.55(d, J=7.4,2$ arom. $\mathrm{H}) ; 4.72(d d, J=5.8,2.5, \mathrm{H}-\mathrm{C}(3)) ; 4.37(d d, J=9.8,5.8$, $1 \mathrm{H}-\mathrm{C}(2)) ; 4.17(d d, J=9.8,2.6,1 \mathrm{H}-\mathrm{C}(2)) .{ }^{13} \mathrm{C}-\mathrm{NMR}(150.9 \mathrm{MHz}): 165.7(s$, $\mathrm{C}=\mathrm{O})$; 139.3, 135.3, 134.7 (3s, 3 arom. C); 131.6, 129.9, 129.1, 128.9, 128.8, $128.4(6 d, 12$ arom. $\mathrm{CH}) ; 127.9(d, \mathrm{PhCH}) ; 127.5,127.0(2 d, 3$ arom. $\mathrm{CH}) ; 124.0$ $(s, \quad \mathrm{C}(7)) ; 112.9 \quad(s, \quad \mathrm{C}(5)) ; 75.9 \quad(t, \quad \mathrm{C}(2)) ; \quad 54.3 \quad(d, \quad \mathrm{C}(3)) . \quad$ ESI-MS ( $\left.\mathrm{MeOH} / \mathrm{CH}_{2} \mathrm{Cl}_{2}+\mathrm{NaI}\right): 859$ (8), 858 (15), 857 (26, [2M+Na] $\left.]^{+}\right), 442$ (14), 441 (30), $440\left(100,[M+\mathrm{Na}]^{+}\right)$. CI-MS $\left(\mathrm{NH}_{3}\right): 418\left(12,[M+\mathrm{H}]^{+}\right), 301$ (12), 300 (21), 299 (100), 282 (17), 256 (7). Anal. calc. for $\mathrm{C}_{24} \mathrm{H}_{19} \mathrm{NO}_{2} \mathrm{~S}_{2}$ (417.55): C 69.04, H 4.59, N 3.35, S 15.36; found: C 68.86, H 4.50, N 3.29, S 15.20. Crystals of 6 suitable for an X-ray crystal-structure analysis were grown from $\mathrm{CH}_{2} \mathrm{Cl}_{2}$.

\section{(3S,5R)-7-Benzylidene-3,9-diphenyl-1-oxa-4,6-dithia-9-azaspiro[4.4]nonan-8-} one (7). Colorless crystals. M.p. $150.3-153.7^{\circ} .[\alpha]_{D}^{24}=-152.8$ (91\% ee). IR: $3057 w, 3028 w, 2926 w, 2863 w, 1697 v s, 1611 m, 1595 w, 1492 s, 1453 m, 1447 m$, 1345vs, 1227m, 1196s, 1150m, 1078m, 1052vs, 1040s, 944w, 900w, 866w, 801w, 761s, 736w, 692vs. ${ }^{1} \mathrm{H}-\mathrm{NMR}(500 \mathrm{MHz}$, at 240K): 7.73 (s, PhCH); 7.58-7.31 (m, 15 arom. $\mathrm{H}) ; 4.49(d d, J=9.7,5.4,1 \mathrm{H}-\mathrm{C}(2)) ; 4.20(d d, J=10.7,5.4, \mathrm{H}-\mathrm{C}(3))$; 4.03 ( $t$-like, $J \approx 10.2,1 \mathrm{H}-\mathrm{C}(2))$. ${ }^{13} \mathrm{C}-\mathrm{NMR}(125.8 \mathrm{MHz}$, at $240 \mathrm{~K}): 165.3(s$, $\mathrm{C}=\mathrm{O})$; 135.0, 134.21, 133.19 (3s, 3 arom. C); 130.1, 129.9, 129.2, 129.13, 129.05, 128.85, 128.83, 128.7, $128.33(9 d, 15$ arom. $\mathrm{CH}) ; 128.26(d, \mathrm{PhCH}) ; 123.8(s$, $\mathrm{C}(7)) ; 111.4(s, \mathrm{C}(5)) ; 76.5(t, \mathrm{C}(2)) ; 55.2$ (d, C(3)). ESI-MS (MeOH+NaI): 859 (6), $858(15), 857\left(25,[2 M+\mathrm{Na}]^{+}\right), 442(15), 441(30), 440\left(100,[M+\mathrm{Na}]^{+}\right)$. Anal. calc. for $\mathrm{C}_{24} \mathrm{H}_{19} \mathrm{NO}_{2} \mathrm{~S}_{2}$ (417.55): C 69.04, H 4.59, N 3.35, S 15.36; found: C 69.21, H 4.76, N 3.31, S 15.21. Crystals of rac-7 suitable for an X-ray crystalstructure analysis were grown from $\mathrm{Et}_{2} \mathrm{O} /$ hexane.

\subsection{X-Ray Crystal-Structure Determination of 3, 4, 6, and 7 .}


See Figs. 1 and 2. ${ }^{11}$ All measurements were made at $160 \mathrm{~K}$ on a Nonius KappaCCD diffractometer ${ }^{12}$ using graphite-monochromated $\operatorname{Mo} K_{\alpha}$ radiation $(\lambda$ $0.71073 \AA$ ) and an Oxford Cryosystems Cryostream 700 cooler. Data reductions were performed with HKL Denzo and Scalepack. ${ }^{13}$ The intensities were corrected for Lorentz and polarization effects, and, in the cases of $\mathbf{3 , 4}$, and 7, an absorption correction based on the multi-scan method ${ }^{14}$ was applied. Equivalent reflections, other than Friedel pairs, were merged. The structures were solved by direct methods using SIR92, ${ }^{15}$ which revealed the positions of all non-H-atoms. In the case of $\mathbf{6}$, there were two symmetry-independent molecules in the asymmetric unit. The atomic coordinates of the two molecules were tested carefully for a relationship from a higher symmetry space group using the program PLATON, ${ }^{16}$ but none could be found, although there is a pseudo-inversion centre relating $89 \%$ of the atoms. The non-H-atoms were refined anisotropically. All of the H-atoms were placed in geometrically calculated positions and refined using a riding model where each $\mathrm{H}$-atom was assigned a fixed isotropic displacement parameter with a value equal to $1.2 \mathrm{U}_{\text {eq }}$ of its parent atom (1.5 $\mathrm{U}_{\text {eq }}$ for methyl groups). Refinements of the structures were carried out on $F^{2}$ using full-matrix least-squares procedures, which minimised the function $\Sigma w\left(F_{\mathrm{o}}{ }^{2}-F_{\mathrm{c}}{ }^{2}\right)^{2}$. A correction for secondary extinction was applied in the cases of 3,6 , and 7. In 4 and 6, one and two reflections, respectively, whose intensities were considered to be extreme outliers, were omitted from the final refinement. Refinements of the absolute structure parameter $^{17}$ yielded values of $-0.04(5),-0.04(7)$, and 0.00(4) for 3, 4, and $\mathbf{6}$, respectively, which confidently confirm that the refined coordinates represent the true enantiomorph in each case. For 7, the largest peak of residual electron density lies within the oxathiolane ring in the vicinity of $\mathrm{O}(1)$ and $\mathrm{C}(2)$, but is inappropriately positioned to be correlated with disorder. Neutral atom scattering factors for non-H-atoms were taken from ${ }^{18 \mathrm{a}}$ and the scattering factors for $\mathrm{H}$-atoms 
were taken from. ${ }^{19}$ Anomalous dispersion effects were included in $F_{\mathrm{c}} ;{ }^{20}$ the values for $f^{\prime}$ and $f^{\prime \prime}$ were those of. ${ }^{18 \mathrm{~b}}$ The values of the mass attenuation coefficients are those of. ${ }^{18 c}$ All calculations were performed using the SHELXL $97^{21}$ program.

Crystal data for 3: $\mathrm{C}_{19} \mathrm{H}_{17} \mathrm{NO}_{2} \mathrm{~S}_{2}, M=355.48$, colorless, prism, crystal dimensions $0.12 \times 0.15 \times 0.28 \mathrm{~mm}$, orthorhombic, space group $P 2{ }_{1} 2{ }_{1} 2_{1}, \mathrm{Z}=4$, reflections for cell determination $57014,2 \theta$ range for cell determination $4-60^{\circ}, a=5.6543(1)$ $\AA, b=12.0695(2) \AA, c=25.3032(4) \AA, V=1726.81(5) \AA^{3}, D_{X}=1.367 \mathrm{~g} \cdot \mathrm{cm}^{-3}$, $\mu\left(\mathrm{MoK}_{\alpha}\right)=0.319 \mathrm{~mm}^{-1}$, transmission factors $(\min ; \max ) 0.876 ; 0.966,2 \theta(\max )=$ $60^{\circ}$, total reflections measured 30374, symmetry independent reflections 5021, reflections with $I>2 \sigma(I) 4222$, parameters refined $219, R$ [on $F ; I>2 \sigma(I)$ reflections $]=0.0338, w R\left(F^{2}\right)[$ all reflections $]=0.0777\left(w=\left[\sigma^{2}\left(F_{\mathrm{o}}{ }^{2}\right)+(0.0323 P)^{2}\right.\right.$ $+0.3459 P]^{-1}$, where $\left.P=\left(F_{\mathrm{o}}{ }^{2}+2{F_{\mathrm{c}}}^{2}\right) / 3\right)$, goodness of fit 1.032 , secondary extinction coefficient $0.005(1)$, final $\Delta_{\max } / \sigma 0.001, \Delta \rho(\max ; \min )=0.34 ;-0.25 \mathrm{e}$ $\AA^{-3}$.

Crystal data for 4: $\mathrm{C}_{19} \mathrm{H}_{17} \mathrm{NO}_{2} \mathrm{~S}_{2}, M=355.48$, colorless, tablet, crystal dimensions $0.07 \times 0.15 \times 0.25 \mathrm{~mm}$, orthorhombic, space group $P 2{ }_{1} 2{ }_{1} 2_{1}, \mathrm{Z}=4$, reflections for cell determination $35017,2 \theta$ range for cell determination $4-60^{\circ}, a=5.5855(1)$ $\AA, b=7.8820(1) \AA, c=39.0360(6) \AA, V=1718.56(5) \AA^{3}, D_{X}=1.374 \mathrm{~g} \cdot \mathrm{cm}^{-3}$, $\mu\left(\mathrm{MoK}_{\alpha}\right)=0.321 \mathrm{~mm}^{-1}$, transmission factors $(\min ; \max ) 0.863 ; 0.979,2 \theta(\max )=$ $60^{\circ}$, total reflections measured 25282, symmetry independent reflections 4973 , reflections with $I>2 \sigma(I) 3564$, parameters refined $218, R$ [on $F$; $I>2 \sigma(I)$ reflections $]=0.0425, w R\left(F^{2}\right)[$ all reflections $]=0.0871\left(w=\left[\sigma^{2}\left(F_{\mathrm{o}}{ }^{2}\right)+(0.0318 P)^{2}\right.\right.$ $+0.2116 P]^{-1}$, where $\left.P=\left(F_{\mathrm{o}}^{2}+2 F_{\mathrm{c}}{ }^{2}\right) / 3\right)$, goodness of fit 1.040 , final $\Delta_{\max } / \sigma 0.001$,

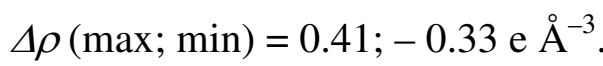


Crystal data for 6: $\mathrm{C}_{24} \mathrm{H}_{19} \mathrm{NO}_{2} \mathrm{~S}_{2}, M=417.55$, colorless, tablet, crystal dimensions $0.12 \times 0.15 \times 0.18 \mathrm{~mm}$, monoclinic, space group $P 2_{1}, \mathrm{Z}=4$, reflections for cell determination 4714, $2 \theta$ range for cell determination $4-55^{\circ}, a=8.5993(1) \AA, b=$ 14.2768(2) $\AA, c=16.5468(2) \AA, \beta=103.5458(6)^{\circ}, V=1974.95(4) \AA^{3}, D_{X}=$ $1.404 \mathrm{~g} \cdot \mathrm{cm}^{-3}, \mu\left(\operatorname{Mo} K_{\alpha}\right)=0.291 \mathrm{~mm}^{-1}, 2 \theta(\max )=55^{\circ}$, total reflections measured 45245, symmetry independent reflections 9001, reflections with $I>2 \sigma(I) 7665$, parameters refined 524; restraints $1, R$ [on $F$; $I>2 \sigma(I)$ reflections] $=0.0402, w R$ $\left(F^{2}\right)[$ all reflections $]=0.0970\left(w=\left[\sigma^{2}\left(F_{\mathrm{o}}^{2}\right)+(0.0421 P)^{2}+0.2619 P\right]^{-1}\right.$, where $P=$ $\left.\left(F_{\mathrm{o}}^{2}+2 F_{\mathrm{c}}{ }^{2}\right) / 3\right)$, goodness of fit 1.053 , secondary extinction coefficient $0.0052(9)$,

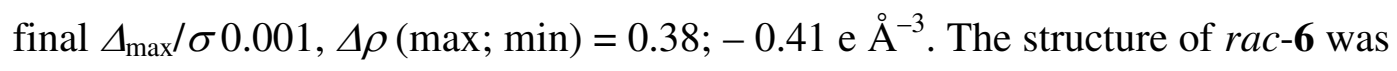
also determined and the data have been deposited. ${ }^{11}$

Crystal data for rac-7: $\mathrm{C}_{24} \mathrm{H}_{19} \mathrm{NO}_{2} \mathrm{~S}_{2}, M=417.55$, colorless, prism, crystal dimensions $0.10 \times 0.18 \times 0.18 \mathrm{~mm}$, triclinic, space group $P^{-}, 1, \mathrm{Z}=2$, reflections for cell determination 29642, $2 \theta$ range for cell determination $4-60^{\circ}, a=$ 8.5150(2) $\AA, b=11.0168(2) \AA, c=12.1739(4) \AA, \alpha=112.9576(9)^{\circ}, \beta=$ 92.4883(9) $)^{\circ}, \gamma=95.597(2)^{\circ}, V=1042.40(5) \AA^{3}, D_{X}=1.330 \mathrm{~g} \cdot \mathrm{cm}^{-3}, \mu\left(\mathrm{Mo} K_{\alpha}\right)=$ $0.275 \mathrm{~mm}^{-1}$, transmission factors $(\min ; \max ) 0.859 ; 0.980,2 \theta(\max )=60^{\circ}$, total reflections measured 28717, symmetry independent reflections 6086, reflections with $I>2 \sigma(I) 4405$, parameters refined 263, $R$ [on $F$; $I>2 \sigma(I)$ reflections] $=$ $0.0568, w R\left(F^{2}\right)[$ all reflections $]=0.1580\left(w=\left[\sigma^{2}\left(F_{\mathrm{o}}{ }^{2}\right)+(0.0615 P)^{2}+0.8250 P\right]^{-1}\right.$, where $\left.P=\left(F_{\mathrm{o}}{ }^{2}+2 F_{\mathrm{c}}{ }^{2}\right) / 3\right)$, goodness of fit 1.024 , secondary extinction coefficient $0.015(4)$, final $\Delta_{\max } / \sigma 0.001, \Delta \rho(\max ; \min )=1.06 ;-0.49 \mathrm{e} \AA^{-3}$. Crystals of a second polymorph of rac-7 were obtained from $\mathrm{CH}_{2} \mathrm{Cl}_{2}$. The structure of this polymorph was also determined and the data have been deposited. ${ }^{11}$

\section{Acknowledgement}


We thank the analytical services of our institute for NMR and mass spectra and elemental analyses, Mr. B. Bürgi for his assistance with the determination of the crystal structures and the Swiss National Science Foundation and F. Hoffmann-La Roche $A G$, Basel, for financial support.

\section{References}

1. M. Blagoev, A. Linden, H. Heimgartner, Helv. Chim. Acta 1999, 82, 1458.

2. M. Blagoev, A. Linden, H. Heimgartner, Helv. Chim. Acta 1999, 82, 2316.

3. M. Blagoev, A. Linden, H. Heimgartner, Helv. Chim. Acta 2000, 83, 3163.

4. C. Fu, A. Linden, H. Heimgartner, Helv. Chim. Acta 2001, 84, 3319.

5. C. Fu, A. Linden, H. Heimgartner, Heterocycles 2002, 58, 333.

6. C. Fu, A. Linden, H. Heimgartner, Helv. Chim. Acta 2003, 86, 2258.

7. C. Fu, A. Linden, H. Heimgartner, Helv. Chim. Acta 2003, 86, 2833.

8. C.K. Johnson, 'ORTEP II. Report ORNL-5138', Oak Ridge National Laboratory, Oak Ridge, Tennessee, 1976.

9. A. Linden, E. M. A. H. Awad, H. Heimgartner, Acta Cryst allogr., Sect. C 1999, 55, 1877.

10. D. Moya Argilagos, R. W. Kunz, A. Linden, H. Heimgartner, Helv. Chim. Acta 1998, 81, 2388.

11. CCDC-225511 - 225516 contain the supplementary crystallographic data for this paper. These data can be obtained free of charge via www.ccdc. cam.ac.uk/conts/retrieving.html (or from the Cambridge Crystallographic Data Centre, 12 Union Road, Cambridge CB2 1EZ, U.K. (fax: +44(0)1223-336033; e-mail: deposit@ccdc.cam.ac.uk).

12. R. Hooft, KappaCCD Collect Software, Nonius BV, Delft, The Netherlands, 1999. 
13. Z. Otwinowski, W. Minor, in 'Methods in Enzymology', Vol. 276, 'Macromolecular Crystallography', Part A, Eds. C. W. Carter Jr., R. M. Sweet, Academic Press, New York, 1997, p. 307.

14. R. H. Blessing, Acta Crystallogr., Sect. A 1995, 51, 33.

15. A. Altomare, G. Cascarano, C. Giacovazzo, A. Guagliardi, M. C. Burla, G. Polidori, M. Camalli, SIR92, J. Appl. Crystallogr. 1994, 27, 435.

16. A. L. Spek, PLATON, Program for the Analysis of Molecular Geometry, University of Utrecht, The Netherlands, 2002.

17. a) H. D. Flack, G. Bernardinelli, Acta Crystallogr. Sect. A 1999, 55, 908;

b) H. D. Flack, G. Bernardinelli, J. Appl. Crystallogr. 2000, 33, 1143.

18. a) E.N. Maslen, A.G. Fox, M.A. O'Keefe, in 'International Tables for Crystallography', Ed. A.J.C. Wilson, Kluwer Academic Publishers, Dordrecht, 1992 Vol. C, Table 6.1.1.1, p. 477; b) D.C. Creagh, W.J. McAuley, ibid. Table 4.2.6.8, p. 219; c) D.C. Creagh, J.H. Hubbell, ibid. Table 4.2.4.3, p. 200.

19. R. F. Stewart, E. R. Davidson, W. T. Simpson, J. Chem. Phys. 1965, 42, 3175.

20. J. A. Ibers, W. C. Hamilton, Acta Crystallogr. 1964, 17, 781.

21. G. M. Sheldrick, SHELXL97, Program for the Refinement of Crystal Structures, University of Göttingen, Germany, 1997. 


\section{Captions:}

Fig. 1. ORTEP Plots ${ }^{8}$ of the molecular structures of a) $\mathbf{3}$ and b) $\mathbf{4}$ (displacement ellipsoids with $50 \%$ probability)

Fig. 2. ORTEP Plots ${ }^{8}$ of the molecular structures of a) one of the two symmetryindependent molecules of $\mathbf{6}$ and b) of 7 (displacement ellipsoids with 50\% probability) 
Fig. 1

a)

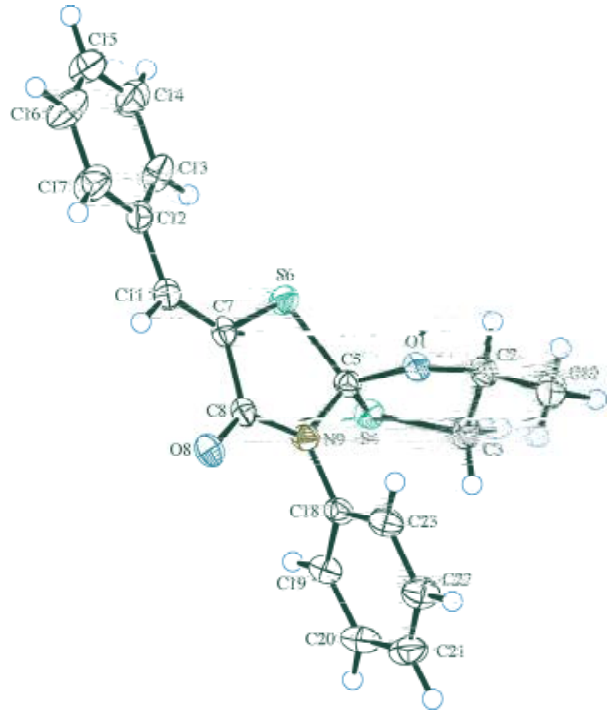

b)

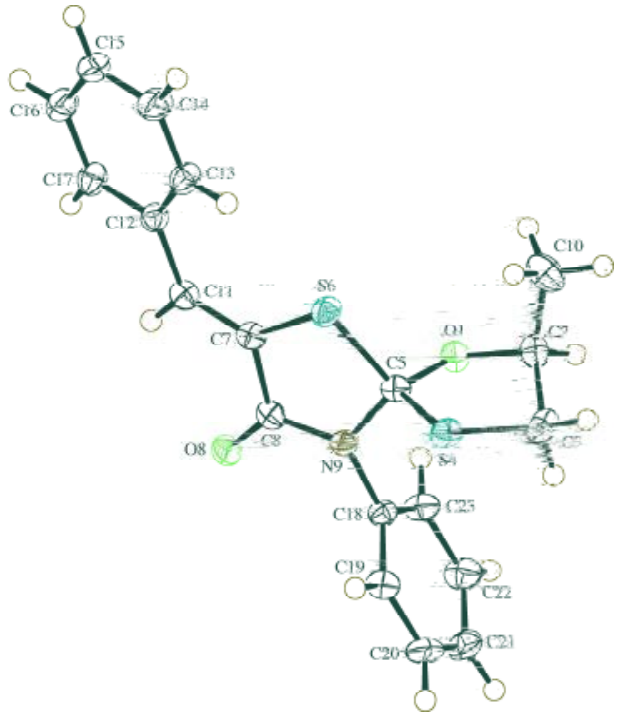


Fig. 2

a)

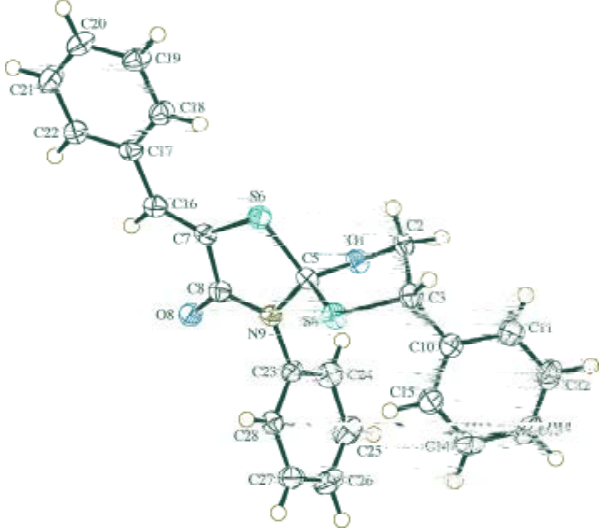

b)

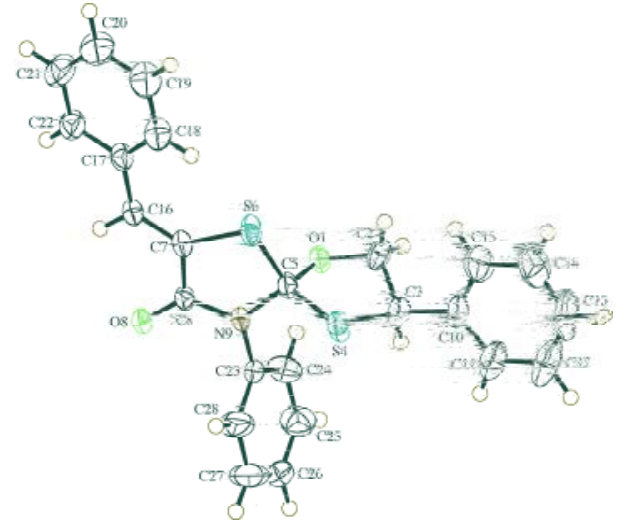


Scheme 1

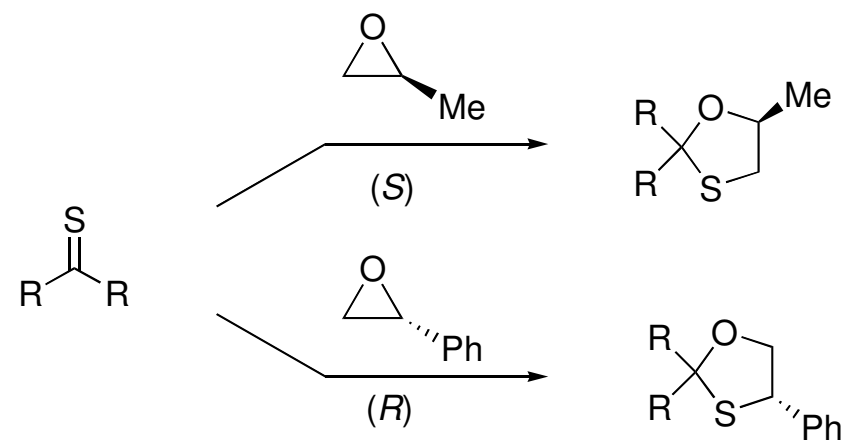


Scheme 2

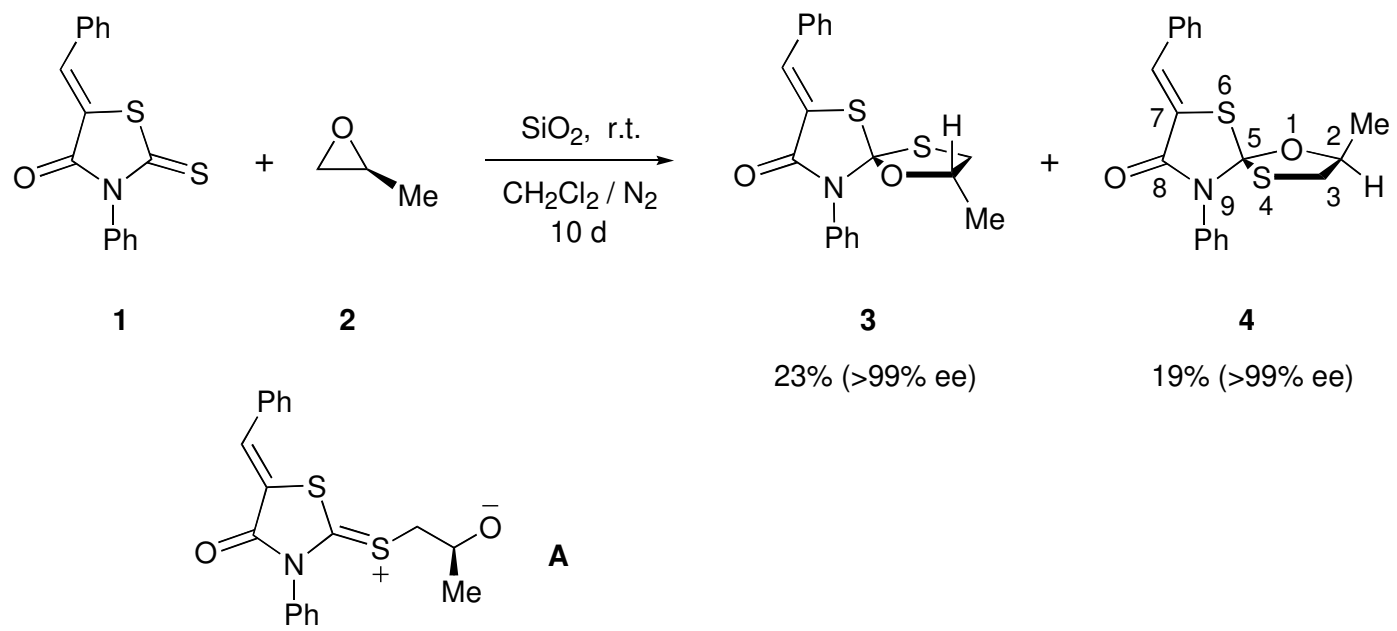


Scheme 3

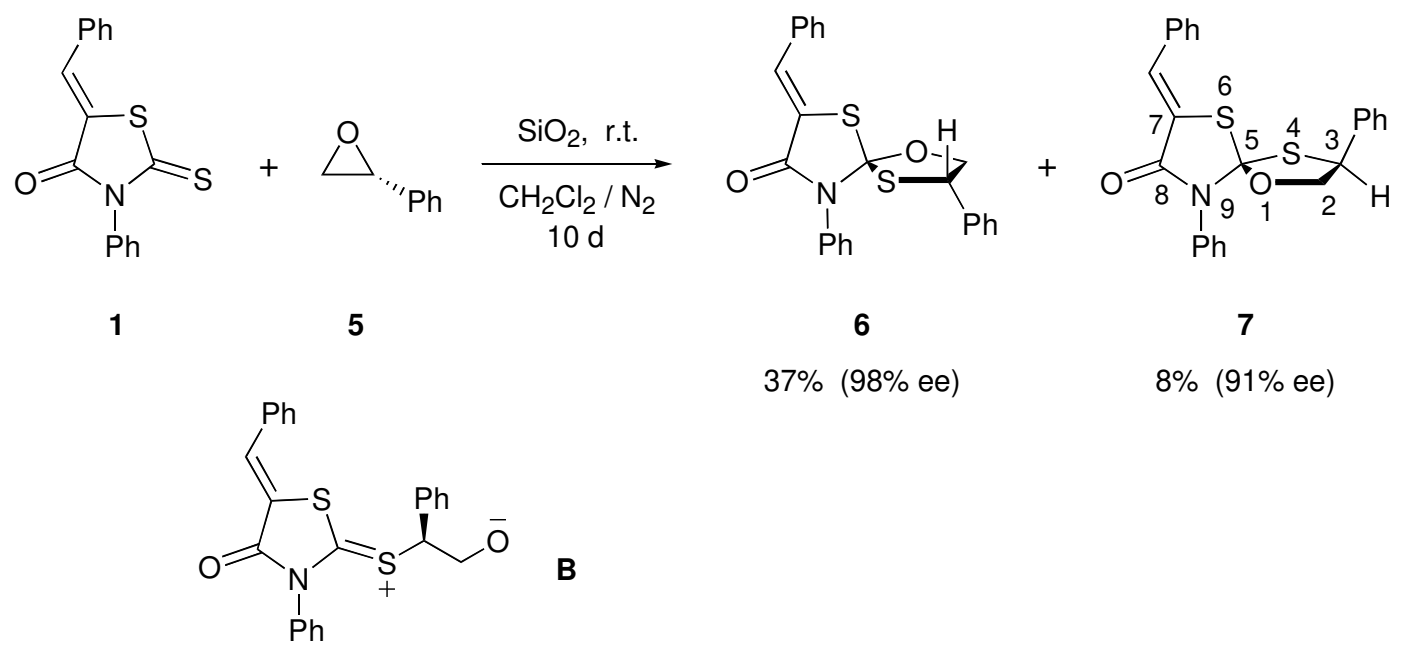




\section{Graphical Abstract}

\section{Regio- and Stereoselective Reactions of a}

\section{Rhodanine Derivative with Optically Active 2-Methyl- and 2-Phenyl-}

\section{oxiranes}

Changchun Fu, ${ }^{\mathrm{a}}$ Marie V. Thrane, ${ }^{\mathrm{b}}$ Anthony Linden, ${ }^{\mathrm{a}}$ and Heinz Heimgartner ${ }^{\mathrm{a}}$

anstitute of Organic Chemistry, University of Zürich, Winterthurerstrasse 190, CH-8057 Zürich, Switzerland

${ }^{\mathrm{b}}$ Department of Chemistry, Technical University of Denmark, DK-2800 Kgs. Lyngby, Denmark
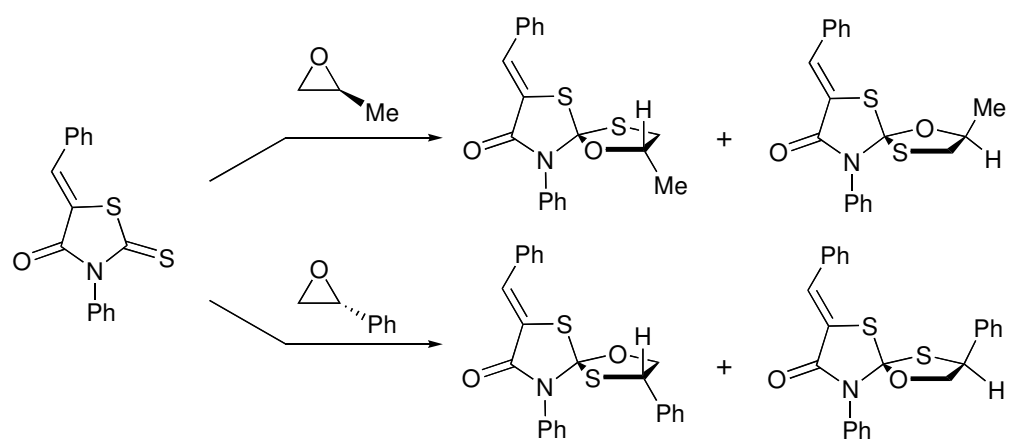